\title{
Presentation order effects in duration discrimination
}

\author{
DONALD G. JAMIESON and WILLIAM M. PETRUSIC \\ Carleton University, Ottawa, Canada
}

\begin{abstract}
Three separate experiments indicate that the second of a pair of durations tends to be overestimated relative to the first. These negative time-order errors are discussed as reliable perceptual phenomena, not explainable in terms of simple response biases, criterion biases, assimilation, or fading traces.
\end{abstract}

Time-order errors occur when the discriminability of a pair of successively presented stimuli depends on the order in which the stimuli are presented. Fechner discovered and named these time-order errors, finding, for example, that he made fewer incorrect judgments with a pair of lifted weights when the lighter weight preceded the heavier than when the weights were presented in the opposite order (Woodworth, 1938). Fechner named this type of error, in which the first of a pair of stimuli was underestimated relative to the second, a negative error, and distinguished it from the positive error which occurred when the first stimulus was overestimated. Subsequently, time-order errors were reported in several modalities, including duration, line length, loudness, brightness, and taste (Needham, 1934; Woodworth, 1938). Reports of time-order errors are common in the early duration-perception literature; however, these reports are often inconsistent, with contradictions arising even within the same laboratory [see Woodrow (1951) for a review of much of the earlier work on the time-order error in duration discrimination]. A number of recent investigators, moreover, have reported finding no systematic time-order errors in duration discrimination (e.g., Allan, Kristofferson, \& Rice, 1974; Creelman, 1962) or have not discussed time-order errors at all (e.g., Abel, 1972; Carbotte \& Kristofferson, 1973). The most recently offered models of duration perception (Allan, Kristofferson, \& Wiens, 1971; Creelman, 1962) provide no mechanism to generate time-order errors. The establishment of the conditions under which time-order errors do occur in duration discrimination must necessarily precede the development of more comprehensive duration perception theories.

Unlike earlier theories, which attributed time-order

This research was supported by grants from the National Research Council of Canada and from Carleton University to Petrusic and by a National Research Council of Canada Postgraduate Scholarship to Jamieson. We are grateful to R. F. Dillon for general advice and to P. Sansoucy for assistance in running subjects. Reprint requests should be mailed to Don Jamieson. Department of Psychology, Carleton University, Ottawa, Canada. K1S 5B6. errors to some memory or perceptual process (Peak, 1940; Woodworth, 1938), some recent theoretical treatments of order effects consider time-order errors to result from subjects' biases. Three types of bias explanations can be distinguished. One type (e.g., Engen, 1971; Luce, 1959) suggests that time-order errors are generated by simple response biases-the tendencies which a subject has to respond in one or another way. In this experiment, these simple response biases are identified with button preferences. Another type of bias, a criterion bias, has been suggested by Luce and Galanter (1963) and by Wickelgren (1968) as a modification of Thurstone's (1927) model for discrimination. In this model, which provides the decision mechanism in Creelman's (1962) duration discrimination model, the internal representation of a stimulus is viewed as a normally distributed random variable which has mean proportional to the magnitude of the stimulus. The presentation of a stimulus pair provides a subject with two values, $X_{1}$ and $X_{2}$, representing the first and second stimulus, respectively. In Thurstone's model, the subject responds "first exceeds second" if $X_{1}>X_{2}$; with the modification, the response is made if $\mathrm{X}_{1}>\mathrm{X}_{2}+\mathrm{C}$. Negative errors are therefore associated with $C>0$, while positive errors are associated with $C<0$. Wickelgren (1968) has proposed a different modification of the Thurstone model. He suggested that the values $X_{1}$ and $X_{2}$ were transformed by biases $b_{1}$ and $b_{2}$, respectively, so that the decision was made with new values $X_{1}^{\prime}=X_{1}-b_{1}$ and $X_{2}^{\prime}=X_{2}-b_{2}$. The response "first exceeds second" would be made if $X_{1}^{\prime}>X_{2}^{\prime}+C$. Thus this model, while similar to the criterion bias model, places a source of time-order error prior to the comparative decision. An examination of the paradigms used in the earlier studies of time-order errors in duration discrimination, revealed that biases may well have been operating. In the most commonly used task (e.g., Philip, 1947; Stott, 1935; Woodrow, 1928, 1935; Woodrow \& Stott, 1936), subjects were asked to decide whether the second duration was longer or shorter than the first. Negative time-order errors, for example, would be generated in these 
experiments by subjects with biases to respond "longer."

The three experiments which are reported here sought to determine the nature of time-order errors in duration discrimination, and to examine the various explanations which have been offered for them. In particular, the effects of simple response bias were evaluated by requiring subjects to select the shorter of a pair of durations on a random one-half of the trials and to select the longer of the pair on the other one-half. To the extent that time-order errors result from simple response biases, here manifest as button preferences, the directions of the errors under the two instruction conditions will differ.

\section{EXPERIMENTS I AND II}

\section{Method}

Experiment I. Two adult students, one male (D) and one temale (S). aged 25 and 26 , volunteered to serve, without pay, for one 30 -min session on each of 8 days. Neither had previously participated in a duration experiment and neither was aware of time-order errors. The experiment was performed in a moderately illuminated experimental room which contained an Electrohome video monitor and a pair of response buttons. One button was marked " 1 " and the other " 2 ," representing the first and second duration of the pair, respectively. Each trial consisted of the following sequence: a word (shorter or longer) was presented on the video screen for $2 \mathrm{sec}$, then was removed; a 650 -msec delay separated the instruction offset from the presentation of the first stimulus; the letter $X$ appeared on the screen, defining the first duration; the screen remained blank for a 650 -msec interstimulus interval; the letter $X$ reappeared on the screen to define the second duration. A trial ended when the subject depressed one of the response buttons, and the next trial began $2 \mathrm{sec}$ later. For the first, third, fifth, and seventh sessions for each subject, the set $\mathrm{A}=$ $[(240,290),(215,315),(5115,5415),(5015,5515)]$ of duration pairs was used (all times in milliseconds). During the other four sessions, the set $B=[(515,1015),(265,765),(7015,8015),(7015,9015)]$ was used. During each session, 64 trials, consisting of four replications of each of the 16 combinations of the four stimulus pairs within a set with two presentation orders [shorter first $(S, L)$ or longer first $(\mathrm{L}, \mathrm{S})]$ and two instructions (shorter or longer) were presented in a completely randomized order. Instructions were written horizontally and in full across the monitor. The letter $X$ and the first letter of each instruction were always presented in the same position near the center of the video screen. All letters were $.63 \mathrm{~cm}$ high and $.28 \mathrm{~cm}$ wide. The subject was seated at a desk which supported the video monitor and the response buttons. approximately $45 \mathrm{~cm}$ from the monitor. The subjects were told to select, by pressing the appropriate response button, the shorter duration on trials beginning with the word "shorter" and the longer duration on trials beginning with the word "longer." They were not given feedback about the accuracy of their responses or information about the expected frequency of each type of response. Timing. sequencing, and stimulus presentation were controlled automatically, with stimulus durations and response latencies accurate to within $1 \mathrm{msec}$. The experimenter remained in the experimental chamber with the subject throughout each session and recorded data manually.

Experiment II. Three undergraduate males were paid an hourly rate to serve for 2 practice and 16 experimental sessions. None had previously participated in a duration experiment. During each session, 64 trials, consisting of four replications of each of the 16 combinations of two instructions with the four duration pairs in the set $A=[(240,290),(215,315),(5115,5415),(5015,5515)]$ and the two orders of presentation, were presented in a completely randomized order. Other aspects of the task and procedure were as for Experiment I, except that following each response the subject was required to report verbally, first the instruction from that trial, then his confidence (rated on a 6-point scale) in the accuracy of the response. Again, the subjects were not given information about the expected frequency of each type of response, and they were not given feedback.

\section{Results and Discussion}

Separate three-way analyses of variance were performed for each subject, with instructions, stimulus pairs, and presentation order as factors, and frequencies of correct responses in each session and in each block of four sessions as the cell entries for Experiments I and II, respectively. Table 1 contains, for each subject, the proportion of correct responses with each duration pair from the A stimulus set under each instruction condition and presentation order. Since much higher proportions of correct responses are associated with pairs presented in the $(S, L)$ rather than in the $(L, S)$ order, all five subjects show negative time-order errors with the long-duration pairs. As well, four subjects show negative errors with the short pairs, while Subject $G$ shows positive errors. Analyses confirm that presentation order had the largest effect

Table 1

Proportion of Correct Responses for Each Stimulus Pair Under Each Instruction and Presentation Order for Each Subject

\begin{tabular}{|c|c|c|c|c|c|c|c|c|c|c|c|}
\hline \multirow[b]{3}{*}{ Stimulus Pair } & \multirow[b]{3}{*}{ Order } & \multicolumn{4}{|c|}{$\begin{array}{c}\text { Experiment I } \\
\text { Instructions }\end{array}$} & \multicolumn{6}{|c|}{$\begin{array}{c}\text { Experiment II } \\
\text { Instructions }\end{array}$} \\
\hline & & \multicolumn{2}{|c|}{ Subject D } & \multicolumn{2}{|c|}{ Subject $S$} & \multicolumn{2}{|c|}{ Subject V } & \multicolumn{2}{|c|}{ Subject G } & \multicolumn{2}{|c|}{ Subject M } \\
\hline & & $\mathbf{S}$ & $\mathbf{L}$ & $\mathbf{S}$ & $\mathrm{L}$ & $\mathrm{S}$ & $\mathrm{L}$ & $\mathbf{S}$ & $\mathrm{L}$ & $\mathrm{S}$ & $\mathrm{L}$ \\
\hline$(240,290)$ & $\begin{array}{l}(\mathrm{S}, \mathrm{L}) \\
(\mathrm{L}, \mathrm{S})\end{array}$ & $\begin{array}{l}.94 \\
.13\end{array}$ & $\begin{array}{l}1.0 \\
.31\end{array}$ & $\begin{array}{l}.81 \\
.31\end{array}$ & $\begin{array}{l}.81 \\
.31\end{array}$ & $\begin{array}{l}.84 \\
.58\end{array}$ & $\begin{array}{l}.91 \\
.45\end{array}$ & $\begin{array}{l}.61 \\
.88\end{array}$ & $\begin{array}{l}.53 \\
.86\end{array}$ & $\begin{array}{l}.83 \\
.25\end{array}$ & $\begin{array}{l}.70 \\
.34\end{array}$ \\
\hline$(215,315)$ & $\begin{array}{l}(\mathrm{S}, \mathrm{L}) \\
(\mathrm{L}, \mathrm{S})\end{array}$ & $\begin{array}{l}1.0 \\
.56\end{array}$ & $\begin{array}{l}.81 \\
.56\end{array}$ & $\begin{array}{l}.94 \\
.63\end{array}$ & $\begin{array}{l}.88 \\
.31\end{array}$ & $\begin{array}{l}.94 \\
.73\end{array}$ & $\begin{array}{l}.98 \\
.70\end{array}$ & $\begin{array}{l}.78 \\
.98\end{array}$ & $\begin{array}{l}.72 \\
.95\end{array}$ & $\begin{array}{l}.86 \\
.38\end{array}$ & $\begin{array}{l}.80 \\
.59\end{array}$ \\
\hline$(5115,5415)$ & $\begin{array}{l}(\mathrm{S}, \mathrm{L}) \\
(\mathrm{L}, \mathrm{S})\end{array}$ & $\begin{array}{l}1.0 \\
.38\end{array}$ & $\begin{array}{l}.94 \\
.38\end{array}$ & $\begin{array}{l}.88 \\
.56\end{array}$ & $\begin{array}{l}.75 \\
.63\end{array}$ & $\begin{array}{l}.89 \\
.37\end{array}$ & $\begin{array}{l}.83 \\
.28\end{array}$ & $\begin{array}{l}.72 \\
.45\end{array}$ & $\begin{array}{l}.84 \\
.45\end{array}$ & $\begin{array}{l}.69 \\
.38\end{array}$ & $\begin{array}{l}.47 \\
.40\end{array}$ \\
\hline$(5015,5515)$ & $\begin{array}{l}(\mathrm{S}, \mathrm{L}) \\
(\mathrm{L}, \mathrm{S})\end{array}$ & $\begin{array}{l}1.0 \\
.38\end{array}$ & $\begin{array}{l}.94 \\
.19\end{array}$ & $\begin{array}{l}.75 \\
.31\end{array}$ & $\begin{array}{l}.69 \\
.31 \\
\end{array}$ & $\begin{array}{l}.91 \\
.34 \\
\end{array}$ & $\begin{array}{l}.94 \\
.25 \\
\end{array}$ & $\begin{array}{l}.87 \\
.43 \\
\end{array}$ & $\begin{array}{l}.70 \\
.41 \\
\end{array}$ & $\begin{array}{l}.75 \\
.47 \\
\end{array}$ & $\begin{array}{r}.58 \\
.33 \\
\end{array}$ \\
\hline
\end{tabular}


Table 2

Mean Latency and Frequency of Correct and Incorrect Responses for Each Stimulus Pair and Confidence Level for Each Subject

\begin{tabular}{|c|c|c|c|c|c|c|c|c|c|c|c|c|c|}
\hline \multirow{3}{*}{$\begin{array}{c}\text { Stimulus } \\
\text { Pair }\end{array}$} & \multirow{3}{*}{$\begin{array}{l}\text { Confi- } \\
\text { dence }\end{array}$} & \multicolumn{4}{|c|}{ Subject V } & \multicolumn{4}{|c|}{ Subject G } & \multicolumn{4}{|c|}{ Subject M } \\
\hline & & \multicolumn{2}{|c|}{ Incorrect } & \multicolumn{2}{|c|}{ Correct } & \multicolumn{2}{|c|}{ Incorrect } & \multicolumn{2}{|c|}{ Correct } & \multicolumn{2}{|c|}{ Incorrect } & \multicolumn{2}{|c|}{ Correct } \\
\hline & & Latency & $\mathbf{N}$ & Latency & $\mathbf{N}$ & Latency & $\mathrm{N}$ & Latency & $\mathbf{N}$ & Latency & $\mathbf{N}$ & Latency & $\mathbf{N}$ \\
\hline$(240,290)$ & $\begin{array}{l}0^{*} \\
1 \\
2 \\
3 \\
4 \\
5 \dagger \\
\text { All }\end{array}$ & $\begin{array}{l}2.43 \\
1.69 \\
1.83 \\
1.97 \\
1.26 \\
1.29 \\
1.77\end{array}$ & $\begin{array}{r}1 \\
1 \\
3 \\
6 \\
2 \\
2 \\
15\end{array}$ & $\begin{array}{l}1.33 \\
1.34 \\
1.18 \\
1.30\end{array}$ & $\begin{array}{r}0 \\
0 \\
23 \\
59 \\
31 \\
0 \\
113\end{array}$ & $\begin{array}{l}4.46 \\
3.48 \\
2.10 \\
2.14 \\
2.34 \\
2.28 \\
2.45\end{array}$ & $\begin{array}{r}1 \\
8 \\
8 \\
15 \\
16 \\
7 \\
55\end{array}$ & $\begin{array}{l}2.62 \\
1.43 \\
2.12 \\
1.46 \\
1.21 \\
1.69\end{array}$ & $\begin{array}{r}0 \\
14 \\
6 \\
11 \\
14 \\
28 \\
73\end{array}$ & $\begin{array}{l}6.88 \\
2.41 \\
2.99 \\
2.39 \\
1.70 \\
2.70\end{array}$ & $\begin{array}{r}1 \\
4 \\
9 \\
15 \\
1 \\
0 \\
30\end{array}$ & $\begin{array}{l}2.81 \\
2.39 \\
2.15 \\
1.74 \\
1.57 \\
2.03\end{array}$ & $\begin{array}{r}0 \\
4 \\
17 \\
37 \\
25 \\
15 \\
98\end{array}$ \\
\hline$(290,240)$ & $\begin{array}{l}0 \\
1 \\
2 \\
3 \\
4 \\
5 \\
\text { All }\end{array}$ & $\begin{array}{l}2.13 \\
1.53 \\
1.71 \\
1.27\end{array}$ & $\begin{array}{r}0 \\
10 \\
13 \\
34 \\
9 \\
0 \\
66\end{array}$ & $\begin{array}{l}2.09 \\
1.93 \\
1.40 \\
1.46 \\
1.63\end{array}$ & $\begin{array}{r}0 \\
9 \\
14 \\
28 \\
11 \\
0 \\
62\end{array}$ & $\begin{array}{l}3.16 \\
2.06 \\
2.42 \\
1.92 \\
2.71 \\
2.27 \\
2.34\end{array}$ & $\begin{array}{r}2 \\
1 \\
1 \\
4 \\
2 \\
7 \\
17\end{array}$ & $\begin{array}{l}2.16 \\
2.64 \\
1.94 \\
1.92 \\
1.64 \\
1.91\end{array}$ & $\begin{array}{r}0 \\
5 \\
10 \\
26 \\
32 \\
38 \\
111\end{array}$ & $\begin{array}{l}3.29 \\
2.67 \\
2.13 \\
2.07 \\
1.30 \\
2.26\end{array}$ & $\begin{array}{r}0 \\
5 \\
21 \\
39 \\
20 \\
5 \\
90\end{array}$ & $\begin{array}{l}3.92 \\
4.51 \\
2.39 \\
2.91 \\
2.05 \\
\\
2.85\end{array}$ & $\begin{array}{r}1 \\
5 \\
7 \\
16 \\
9 \\
0 \\
38\end{array}$ \\
\hline$(215,315)$ & $\begin{array}{l}0 \\
1 \\
2 \\
3 \\
4 \\
5 \\
\text { All }\end{array}$ & $\begin{array}{l}1.62 \\
4.71 \\
1.09 \\
1.05 \\
1.77\end{array}$ & $\begin{array}{l}0 \\
1 \\
1 \\
2 \\
2 \\
0 \\
6\end{array}$ & $\begin{array}{r}1.31 \\
1.26 \\
1.02 \\
.84 \\
1.17\end{array}$ & $\begin{array}{r}0 \\
0 \\
12 \\
60 \\
49 \\
1 \\
122\end{array}$ & $\begin{array}{l}2.73 \\
2.19 \\
2.45 \\
1.89 \\
2.28\end{array}$ & $\begin{array}{r}0 \\
0 \\
4 \\
10 \\
11 \\
7 \\
32\end{array}$ & $\begin{array}{l}2.32 \\
2.40 \\
2.04 \\
1.60 \\
1.27 \\
1.49\end{array}$ & $\begin{array}{r}0 \\
2 \\
4 \\
11 \\
16 \\
63 \\
96\end{array}$ & $\begin{array}{l}4.46 \\
2.91 \\
2.41 \\
2.83 \\
2.07 \\
\\
2.72\end{array}$ & $\begin{array}{r}1 \\
2 \\
3 \\
12 \\
4 \\
0 \\
22\end{array}$ & $\begin{array}{l}3.36 \\
3.37 \\
2.30 \\
1.73 \\
1.77 \\
2.08\end{array}$ & $\begin{array}{r}0 \\
2 \\
8 \\
34 \\
33 \\
29 \\
106\end{array}$ \\
\hline$(315,215)$ & $\begin{array}{l}0 \\
1 \\
2 \\
3 \\
4 \\
5 \\
\text { All } \\
\end{array}$ & $\begin{array}{l}3.03 \\
1.28 \\
1.52 \\
1.41 \\
1.41\end{array}$ & $\begin{array}{r}1 \\
1 \\
12 \\
16 \\
4 \\
0 \\
34\end{array}$ & $\begin{array}{r}2.23 \\
1.77 \\
1.26 \\
.99 \\
1.22 \\
1.32 \\
\end{array}$ & $\begin{array}{r}0 \\
2 \\
23 \\
39 \\
27 \\
3 \\
94\end{array}$ & $\begin{array}{r}.98 \\
2.75 \\
1.61 \\
2.02\end{array}$ & $\begin{array}{l}0 \\
0 \\
0 \\
1 \\
2 \\
1 \\
4\end{array}$ & $\begin{array}{l}3.41 \\
3.50 \\
1.91 \\
1.75 \\
1.36 \\
1.55\end{array}$ & $\begin{array}{r}0 \\
2 \\
1 \\
12 \\
28 \\
81 \\
124\end{array}$ & $\begin{array}{l}2.69 \\
2.34 \\
1.93 \\
1.93 \\
1.84 \\
2.08\end{array}$ & $\begin{array}{r}0 \\
4 \\
17 \\
29 \\
13 \\
3 \\
66\end{array}$ & $\begin{array}{l}3.03 \\
2.71 \\
2.06 \\
1.90 \\
2.23 \\
2.17\end{array}$ & $\begin{array}{r}0 \\
3 \\
10 \\
27 \\
19 \\
3 \\
62\end{array}$ \\
\hline
\end{tabular}

*Guess

tCertain

upon accuracy $[F(1,48)=26.15,25.14,180.88$, $100.64 ; \mathrm{p}<.001, .001, .001, .001$, for Subjects D, S, $\mathrm{V}$, and $\mathrm{M}$, respectively]. The simple response biases are sizeable for some subjects, as confirmed by significant interactions of Stimuli by Instruction $[F(3,48)=3.23 ; \mathrm{p}<.05$, for $\mathrm{M}]$ and Order by Instruction $[F(1,48)=5.84,10.07 ; p<.05, .01$, for $V$ and $M$, respectively]. These biases, however, are nowhere sufficient to alter the direction of the time-order error between instruction conditions, as predicted by the simple response bias explanation. The duration pairs were not equally discriminable, of course $[F(3,48)=5.42,4.00,7.54,11.64,6.24 ; p<$ $.01, .05, .001, .001, .001$, for $D, S, V, G$, and $M$, respectively), and the time-order errors changed, either in magnitude (for $\mathrm{V}$ and $\mathrm{M}$ ) or in direction (for $G$ ), with different duration pairs, resulting in significant interactions of Stimuli by Order $[F(3,48)$ $=10.66,21.90,4.71 ; \mathrm{p}<.001, .001, .01$, for $\mathrm{V}, \mathrm{G}$, and $M$, respectively]. A parallel ANOVA performed on the $B$ set data from Experiment I revealed a significant main effect of order $[F(1,48)=10.89$, $7.38 ; p<.01, .01$, for $D$ and $S$, respectively). No other interactions or main effects approached the .05 level in any of the analyses.

Table 2 contains the frequencies and mean latencies of correct and incorrect responses for each short stimulus pair and confidence level for each of the three subjects in Experiment II. These latencies, measured from the onset of the second duration, have two properties which are of interest here: faster responses are associated with higher confidence, and, for a given cell, dominant responses (those occurring more frequently) tend to be faster than nondominant responses. With reasonable assumptions relating response speed to the proximity of each observation to the criterion point (discussed by Thomas, 1971), these latency properties are perfectly consistent with the general Thurstone model. ${ }^{1}$ In general, the relationships among confidence rating, latency, and frequency are compatible with the Thurstone model (see, for example, Norman \& Wicklegren, 1969; Wicklegren, 1968).

With the long-duration pairs, two subjects regularly responded correctly before the termination of the second duration. On approximately .18 of the trials 
with the ordered pair $(5115,5415)$ and on .16 of the trials with the ordered pair $(5015,5515)$. Subject $V$ responded before the second duration had physically exceeded the first duration. The comparable proportions for $D$ were .38 and .25 . Since these responses did not occur before the second duration had been presented for at least $3.8 \mathrm{sec}$, and since neither comparable correct anticipations in the (L,S) order nor incorrect anticipations in the $(S, L)$ order occurred, these fast responses cannot be considered a variety of fast guess response (Ollman, 1966). For the same reasons, these responses do not indicate judgments based on single stimuli as Allan et al (1974) reported finding when much shorter durations were compared. Rather, it seems that the fast responses reflect a particular strategy in which the subjects compared, at intervals during the presentation of the second duration, the current value of that stimulus with the remembered value for the first. Alternatively, the subjects might simply have reproduced the first duration during the presentation of the second, selecting as the shorter, that stimulus which first terminated. While the former strategy, at least, readily admits all explanations of the time-order errors, these fast responses provide a further measure of the time-order errors, permitting an estimate of the amount by which the second duration was judged greater than the first on a trial.

The next experiment was designed to further examine time-order errors in duration discrimination by varying ISI and by observing the errors in a larger sample of subjects.

\section{EXPERIMENT III}

\section{Method}

Ejghteen introductory psychology students served for approximately $45 \mathrm{~min}$ in return for course credit. Each subject served for two sessions. one with a $1 / 2$-sec ISI and the other with one of 2,4 , or 8 sec. Six subjects received the 2 -sec ISI, six the 4 , and six the 8 , with three subjects in each group receiving the $1 / 2$-sec ISI during the first and three during the second session. A single stimulus set, $\mathrm{C}=[(5400,5400),(5000,5000),(5000,5400)$, $(5400,5000)$ ], was used in both sessions. Stimulus durations were defined by the illumination of a small light source-a single red Monsanto light-emitting diode (MV 5020). The diode, which was $.47 \mathrm{~cm}$ in diam and had a rise/fall time of $50 \mathrm{nsec}$, was mounted on a clear plastic panel placed in front of the video monitor. During each session, 64 trials, consisting of eight replications of each of the eight combinations of two instructions with four duration pairs, were presented in a completely randomized order. A microphone was placed in the experimental chamber permitting the experimenter to monitor the subject's instruction recall and confidence ratings from a separate room. Other aspects of the procedure and task were as for Experiment II.

\section{Results and Discussion}

Data for each subject were collapsed over instructions prior to any analyses. This procedure eliminates the effects of simple response biases, since

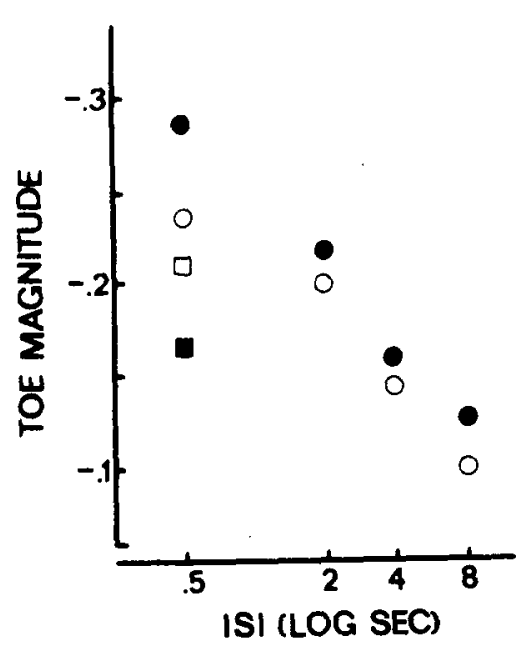

Figure 1. Decrease in the magnitude of the negative time-order errors with hicreasiny, ISI in log seconds. Data averaged over the 18 subjects in Exp sriment III. Closed circles represent time-order errors for the ec ual pairs, while open circles represent time-order errors for the unequal pairs. The average time-order errors associated with the long stimulus pairs [open square] and the short stimulus pairs [closed square] from Experiments Iand 11 are included for comparison purposes.

these effects ${ }^{2}$ should be oppositely directed under the two instruction conditions. To obtain an estimate of the overall magnitude and direction of the time-order error and to facilitate comparison of the equal and unequal pairs, two measures ${ }^{3}$ of time-order errors were taken. First, the proportion of responses meaning that the first duration exceeded the second was computed separately for each subject for the $(5000,5000)$ and $(5400,5400)$ pairs, and .5 subtracted from this value. Second, the proportion of correct responses made with the pair $(5000,5400)$ was subtracted from that with the pair $(5400,5000)$ and this value halved. Each response measure, therefore, gives a separate estimate of the time-order error for each subject, and each is negative whenever the time-order error is. Seventeen of the 18 subjects showed negative errors at the $1 / 2$-sec ISI using both of these measures. For the six subjects in the 2-, 4-, and 8 -sec ISI conditions, the frequencies were 6,5 , and 5 , respectively, with the equal pairs and 5,5 , and 4 with the unequal pairs. Figure 1 shows that the means of each of these measures became less negative as the ISI increased. Analyses indicated that the $1 / 2-\mathrm{sec}$ ISI differed from the other ISIs $[F(1,17)=8.32, p<.01]$ and that the two measures did not differ significantly $[F(1,17)=3.59, p=.072]$. The points for the 2-, 4-, and 8 -sec ISI did not differ significantly $(F<1)$. The decrease in amount of time-order error as ISI increased was not due to increasing variance in the representation of the first duration, since this would 
require the overall proportion of correct responses with unequal pairs to approach .5 . On the contrary, the effect of increasing ISI was to produce a slight increase in the proportion correct, with $.63, .66, .68$, and .69 being the mean proportions of correct responses made with the unequal pairs at the $1 / 2-, 2-$, 4-, and 8-sec ISI, respectively. The decrease in the magnitude of the time-order error with increasing ISI appears after conditioning on the order of presentation, with the $(5000,5400)$ pair associated with decreasing proportions of correct responses $(.86$, $.83, .81, .79)$ and the pair $(5400,5000)$ associated with increasing proportions of correct responses $(.40, .46$, $.55, .59)$ as ISI increased. This relationship between time-order error magnitude and ISI is troublesome for the bias explanations, therefore, since it requires the bias, in an individual subject, to be ISI-dependent, with the magnitude of the bias decreasing as the ISI increases. As well, the notions that negative time-order errors result from the fading of the memory trace of the first duration (e.g., Michon, 1967) or from the assimilation of that trace to some smaller value during the ISI (e.g., Woodrow, 1935) are contra-indicated, since both explanations would require time-order errors to become increasingly negative as the ISI increased, not, as Figure 1 shows, to become less negative.

\section{GENERAL DISCUSSION}

The time-order errors found in these experiments are quite uniformly negative: for durations near $5 \mathrm{sec}$, 22 of 23 subjects show negative errors at the $500-\mathrm{msec}$ ISI. These time-order errors do not result from simple response biases, however, since they do not change direction when instructions are changed. Moreover, they are not explainable in terms of the fading or assimilation of the memory trace of the first-presented duration, since the time-order errors show a regular and consistent decline in magnitude as ISI increases. Finally, the demands that different subjects must adopt similar biases and that the biases must change regularly with ISI place both the criterion and predecisional bias explanations in doubt. Rather, it may be that these results are due to perceptual effects which cause the second of a pair of durations to be seen as proportionally different from the first. The magnitude of such an effect might well be expected to decline as ISI increased.

A major methodological difference may help to reconcile the present results with the apparent failures to observe time-order errors in several recent duration-discrimination studies: While the experiments which did not report time-order errors (e.g., Abel, 1972; Creelman, 1962) provided both feedback concerning response accuracy and extended practice at the task, the present experiments provided neither. In fact, perceptually rooted time-order errors may have occurred in the experiments cited, but were noi observed because the practice with feedback caused the subjects to adopt biased criteria, in the Luce-Galanter sense, to increase accuracy. Various ways in which feedback might lead to the establishment of such biased criteria have been discussed, for example, by Dorfman and Biederman (1971) and by Thomas (1973), and, in fact, any approximately constant effect could be overcome by the selection of a suitably biased criterion (Luce \& Galanter, 1963). In this case, it would be the failure to observe time-order errors and not the observation of the errors which would be attributable to criterion bias.

\section{REFERENCES}

Abel, S. M. Duration discrimination of noise and tone bursts. Journal of the Acoustical Society of America, 1971, 51, 1219-1223.

Allan, L. G., Kristofferson, A. B., \& Rice, M. E. Some aspects of perceptual coding in visual duration discrimination. Perception \& Psychophysics, 1974, 15, 83-88.

Allan, L. G., Kristofferson, A. B., \& Wiens, E. W. Duration discrimination of brief light flashes. Perception \& Psychophysics, 1971, 9, 327-334.

Carbotte, R. M., \& Kristofferson, A. B. On energydependent cues in duration discrimination. Perception \& Psychophysics, 1973, 14, 501-505.

Creelman, C. D. Human discrimination of auditory duration. Journal of the Acoustical Society of A merica, 1962, 34, 582-593.

Dorfman, D. D., \& Biederman, M. A learning model for a continuum of sensory states. Journal of Mathematical Psychology, 1971, 8, 264-285.

Engen, T. Psychophysics I. Discrimination and detection. In J. W. Kling and L. A. Riggs (Eds.), Woodworth and Schlosberg's Experimental psychology. New York: Holt, Rinehart and Winston, 1971.

1.AMING, D. R. Information theory of choice-reaction times. New York: Academic l'ress, 1968.

LUCE, R. D. Individual choice behavior. New York: Wiley, 1959.

Luce, R. D., \& Galanter, E. Discrimination, In R. D. Luce, R. R. Bush, and E. Galanter (Eds.), Handbook of mathematical psychology (Vol. I). New York: Wiley, 1963.

MichoN, J. A. Timing in temporal tracking. Soesterberg, The Netherlands: Institute for Perception RVO-TNO, 1967.

NeEDhaM, J. G. The time-error in comparison judgments. Psychological Bulletin, 1934, 31, 229-243.

Norman, D. A., \& Wickelgren, W. Strength theory of decision rules and latency in retrieval from short-term memory. Journal of Mathematical Psychology, 1969, 6, 192-208.

Ollman, R. Fast guesses in choice reaction time. Psychonomic Science, 1966, 6, 155-156.

PEAK, H. The time-order error in successive judgments and in reflexes. III. Time error theories. Psychological Review, 1940. 47, 1-20.

Philip, B. R. The effect of interpolated and extrapolated stimuli on the time-order error in the comparison of temporal intervals. Journal of General Psychology, 1947, 36, 173-187.

P'IKE. A. R. Latency and relative freyuency of response in psychopliysical discrimination. British Journal of Mathematical and Statistical Psychology. 1968, 21, 161-182. 
Stotт, L. H. Time-order errors in the discrimination of short tonal durations. Journal of Experimental Psychology, 1935, 18. 741-766.

Thomas, E. A. C. Sufficient conditions for monotone hazard rate: An application to latency-probability curves. Journal of Mathematical Psychology, 1971, 8, 303, 332.

Tномаs, E. A. C. On a class of additive learning models: Error-correcting and probability matching. Journal of Mathematical Psychology, 1973, 10, 241-265.

Thurstone, L. L. A law of comparative judgment. Psychological Review, 1927, 34, 273-286.

Wickelgren, W. A. Unidimensional strength theory and component analysis of noise in absolute and comparative judgments. Journal of Mathematical Psychology, 1968, 5, 102-122.

Woodrow, H. Behavior with respect to short temporal forms. Journal of Experimental Psychology, 1928, 11, 174.

Woonrow, $H$. The effect of practice upon time-order errors in the comparison of temporal intervals. Psychological Review, $1935,72,127-152$.

Woodrow, H. Time perception.: In S. S. Stevens (Ed.), Handbook of experimental psychology. New York: Wiley, 1951.

Woodrow, H., \& Stotr, L. H. The effect of practice upon positive time-order errors. Journal of Experimental Psychology, $1936,19,694-705$.

Woodworth, R. S. Experimental psychology. New York: Holt, Rinehart and Winston, 1938.

\section{NOTES}

1. As well, a number of alternative models which specify the form of the latency probability function, such as the unbiased random walk model (Laming. 1968: Pike, 1968), are incompatible with the Table 2 datia.

2. Nevertheless. simple response biases were not large. For example, the direction of the time-order error for the unequal pairs reversed only 4 of a possible 36 times as instruction changed \{using $\mathrm{P}[\mathrm{C} \mid(5000), 5400)] \mathrm{P}[\mathrm{C} \mid(5400.5000)]$ as a measure of time-order error\}.

3. The first measure was based on the assumption that the proportions of responses meaning "first exceeds second" were at chance levels except for the effect of the time-orde error (toe), i.e., that $\mathrm{P}(1>2)=.5+$ toe. for the $(5000,5000)$ and $(5400,5400)$ pairs. Thus $P(1>2)-.5=$ toe. The second nea:ure was based on the assumption that the proportions of correct responses with the pair $(5400.5000)$ were determined by the discriminability of the pair (D), except for the effect of the time-order error, i.e., that $\mathrm{P}[\mathrm{C} \mid(\mathrm{L} . \mathrm{S})]=\mathrm{D}+$ toe. Similarly, for the $(5000,5400)$ pair, $P[C(S, L)]=D$ toe. Thus $1 / 2\{P[C \mid(L, S)\}-P[C|(S, L)|\}=$ toe. Both measures assume that the effects produced by/on the 5,000 and 5,400-msec durations were approximately equal.

(Received for publication June 14, 1974: revision received September 26. 1974.) 